\title{
Mangrove Vegetation Dynamics of the Tanbi Wetland National Park in The Gambia
}

\author{
Adam Ceesay ${ }^{1, *}$, N'Da Hypolite Dibi ${ }^{2}$, Ebrima Njie ${ }^{3}$, Matthias Wolff ${ }^{4}$, Tidiani Koné ${ }^{5}$ \\ ${ }^{1}$ WASCAL Graduate Research Program in Climate Change and Biodiversity, Felix Houphouet Boigny University, Côte d'Ivoire \\ ${ }^{2}$ University Centre for Research and Remote Sensing Application (CURAT), /National Floristic Center (CNF), \\ Felix Houphouet Boigny University, Côte d'Ivoire \\ ${ }^{3}$ Department of Natural Sciences, University of The Gambia, The Gambia \\ ${ }^{4}$ Leibniz Center for Tropical Marine Ecology, University of Bremen, Germany \\ ${ }^{5}$ UFR Environment, Jean Lorougnon Guédé University, Côte d'Ivoire
}

Copyright $\bigcirc 2017$ by authors, all rights reserved. Authors agree that this article remains permanently open access under the terms of the Creative Commons Attribution License 4.0 International License

\begin{abstract}
Changes in mangrove vegetation have been identified as important indicators of environmental deterioration. The mangroves of the Tanbi Wetland National Park (TWNP) connect the Atlantic coast with the estuary of the River Gambia and as such, play an invaluable role in the agriculture, tourism and fisheries sectors of The Gambia. Our research seeks to understand the long-term changes in the mangrove vegetation in order to strengthen the formulation of sustainable alternative livelihoods and adaptation strategies to climate change. Mangrove vegetation dynamics was assessed by remote sensing, using decadal Landsat images covering 1973 - 2012. Physicochemical parameters were analyzed during the rainy and dry seasons for correlation with climate data. Our findings indicate that the long-term changes in salinity $(24.5$ and $35.8 \mathrm{ppt})$ and water temperature $\left(27.6^{\circ} \mathrm{C}\right.$ and $\left.30.2^{\circ} \mathrm{C}\right)$ during the rainy and dry seasons respectively are retarding mangrove growth. Mangrove vegetation cover declined by $6 \%$, while grassland increased by $56.4 \%$. This research concludes that long-term hyper-salinity is the cause for the stunted vegetation and lack of mangrove rejuvenation in TWNP. We propose that specialized replanting systems such as the use of saplings be adopted instead of the conventional use of propagules. Alternative livelihoods also need to be diversified to support coastal communities.
\end{abstract}

Keywords Tanbi Wetland, Mangrove Vegetation, Hyper-salinity, Climate Change, Land Use

\section{Introduction}

Mangroves are unique tropical and subtropical plants that are specially adapted to thrive in inundated and saline intertidal zones [1]. Based on their ability to cope with high salt concentration and regular inundation, they form the primary features within estuarine ecosystems [2]. Mangroves form habitats that support numerous species through the provision of spawning grounds, essential organic nutrients like nitrogen and carbon [3], as well as refuges from predation $[4,5]$. They also serve as natural windbreakers that protect shorelines from erosion, while serving as a rich source of food, water and employment for coastal communities [6].

Globally, mangrove coverage has declined from 198,000 $\mathrm{km}^{2}$ in 1980 to $150,000 \mathrm{~km}^{2}$ in 2012 [7]. This decline has been attributed to the impacts of natural and anthropogenic processes [8]. The impacts of socio-economic activities such as agriculture, settlement and ecotourism; coupled with the recent changes in climate variables such as atmospheric temperature, rainfall and sea level have led to reduced habitat integrity (hyper-salinity) [9]. Such drastic changes in hydrology were reported to induce stunting of Avicennia marina L. stands and denaturing of terminal buds in Rhizophora mangle L. seedlings in the USA [10]. Austin et al. [11] also suggested that modest changes in rainfall and temperature caused significant reductions in mean annual runoff and increased stream salt concentrations in Murray-Darlin Basin (Australia), resulting in loss of mangrove vegetation.

For proper functioning of estuaries, a healthy vegetation (mangrove) is prerequisite [12]. The U.S. Fish and Wildlife Services [13] reported that mangroves improve water quality and clarity by filtering upland runoff and trapping waterborne sediments/debris and at the same time recycling and maintaining the nutrient mass balance of the estuarine ecosystems. Vannucci [3] also suggested that mangroves serve as a sink for carbon, heavy metal pollutants and other toxic compounds, making their regulatory role very vital for cushioning the effect of seasonal variability in coastal waters. 
Thus, the degradation of mangroves can shake the estuarine physicochemical balance and stall important biochemical processes such as photosynthesis, decomposition and nutrient uptake, spawning activities and consequently growth and reproduction of the dwelling fauna $[14,15]$. However, current research shows little attention to the impacts of climate and anthropogenic processes on estuaries, especially for countries such as The Gambia in West Africa where population density and industrial development is highest along the coast [16].

This research seeks to assess the long-term changes in mangrove vegetation of the Tanbi Wetland National Park (TWNP) in relation to the climate-induced changes in the estuarine hydrology. Designated a Ramsar wetland of international importance in 2007 in The Gambia [17], the TWNP served as an important socio-economic hub for fisheries, agriculture and tourism [18]. By integrating direct in-situ observation data with remotely sensed data, this research provides a comprehensive assessment accounting for both anthropogenic and natural drivers of change in mangrove estuaries, thus filling the existing information gap on the synergistic impacts of land use and climate change and variability. This paper will also provide useful recommendations for the rational use of the mangrove estuary for coastal communities while maintaining a healthy
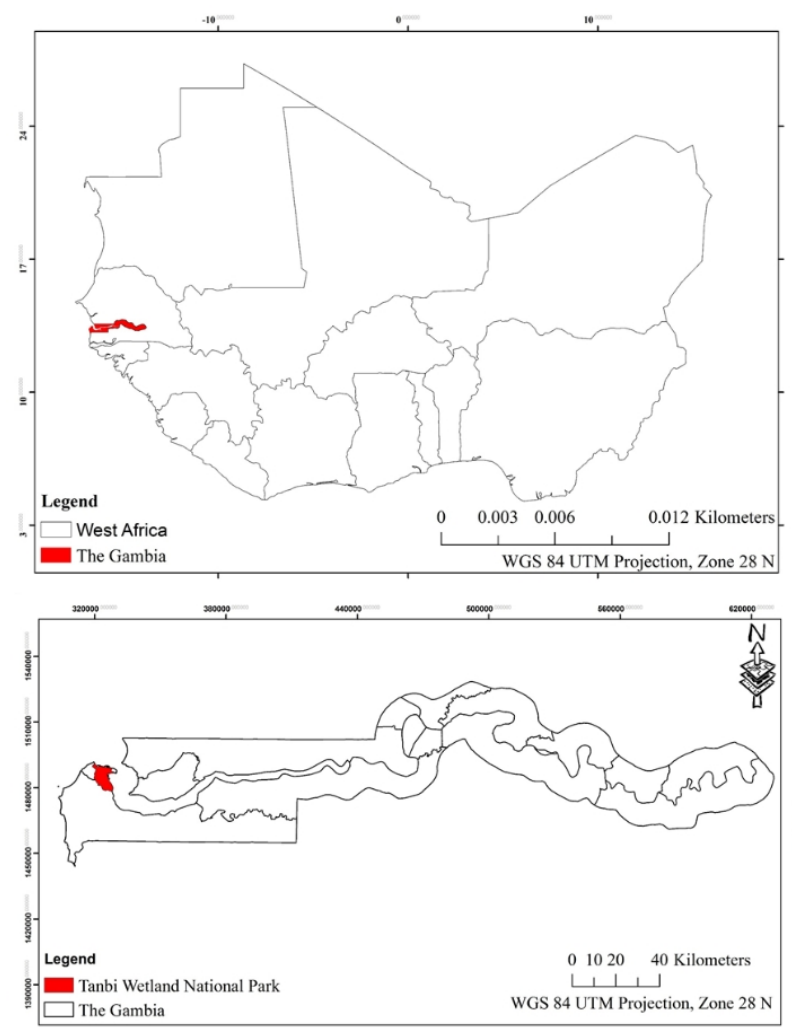

Figure 1. Location of Tanbi Wetland National Park in The Gambia, with the sampling stations marked (red star).

Mangroves in TWNP are comprised of Rhizophora mangle L. (red mangrove), Avicennia germinans L. (black mangrove), Laguncularia racemosa L. (white mangrove) and Rhizophora harrisonii L. [23] (Figure 2). mangrove vegetation cover. Most importantly, findings of conservation in The Gambia and provide recommendations for better management of the TWNP.

\section{Materials and Methods}

\subsection{Study Site}

The Tanbi Wetland National Park (TWNP) (Figure 1) is a lowland area with a mean altitude of 1 to $1.6 \mathrm{~m}$ above sea level, extending between $13^{\circ} 23 \mathrm{~N}-16^{\circ} 34 \mathrm{~W}$ and $13^{\circ} 26 \mathrm{~N}-$ $16^{\circ} 38 \mathrm{~W}$ [17]. With an area of about 6300ha [19], the TWNP is flanked on the Southeast by the River Gambia and to the Northwest by the Atlantic Ocean and the Greater Banjul Area (GBA) in the Southwest [18], as well as the capital city Banjul on the East [20]. Located in the Sahelo-Sudanian climate zone, TWNP has a long dry season (October - June) and a short rainy season (June - October) [21]. Prominent land use types include: agricultural lands and dumping grounds; settlement areas; ubiquitous oyster processing zones; cruising boat docks for river excursions and others $[22]$.

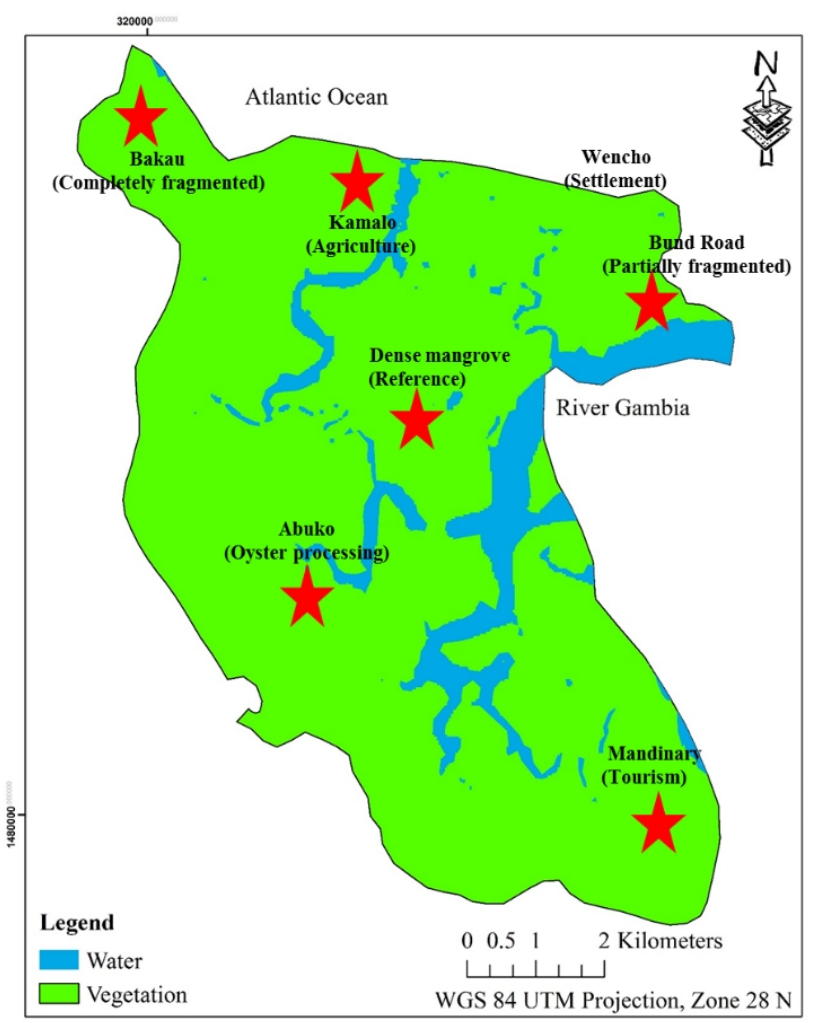
this research will serve as a baseline for mangrove 

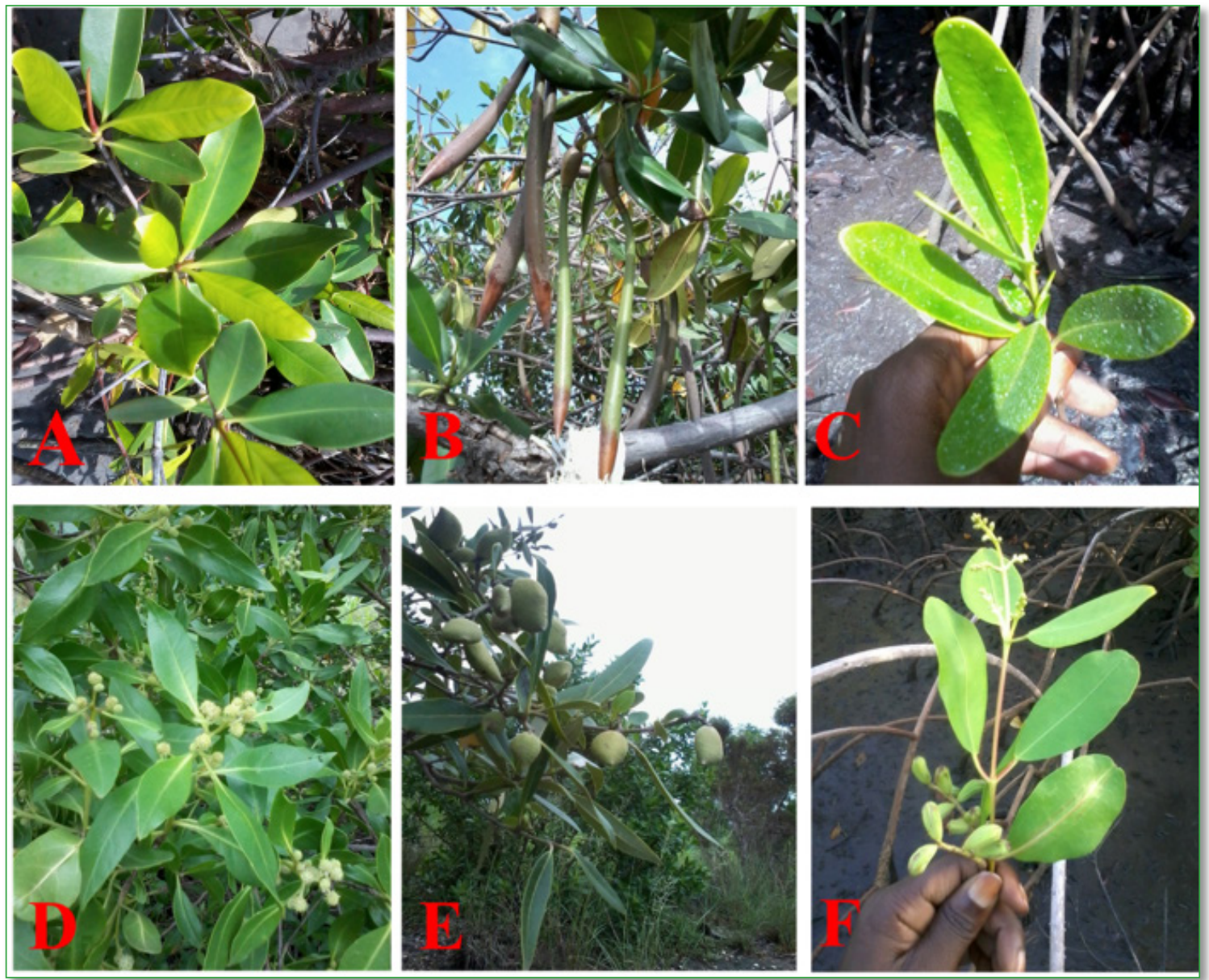

Figure 2. Dominant mangrove species in Tanbi Wetland National Park in The Gambia in 2014. Rhizophora mangle leaves (A) and propagules (B), Laguncularia racemosa leaves (C) with "fruits" and flowers (F), and Avicennia germinans leaves with flowers (D) and "fruits" (E).

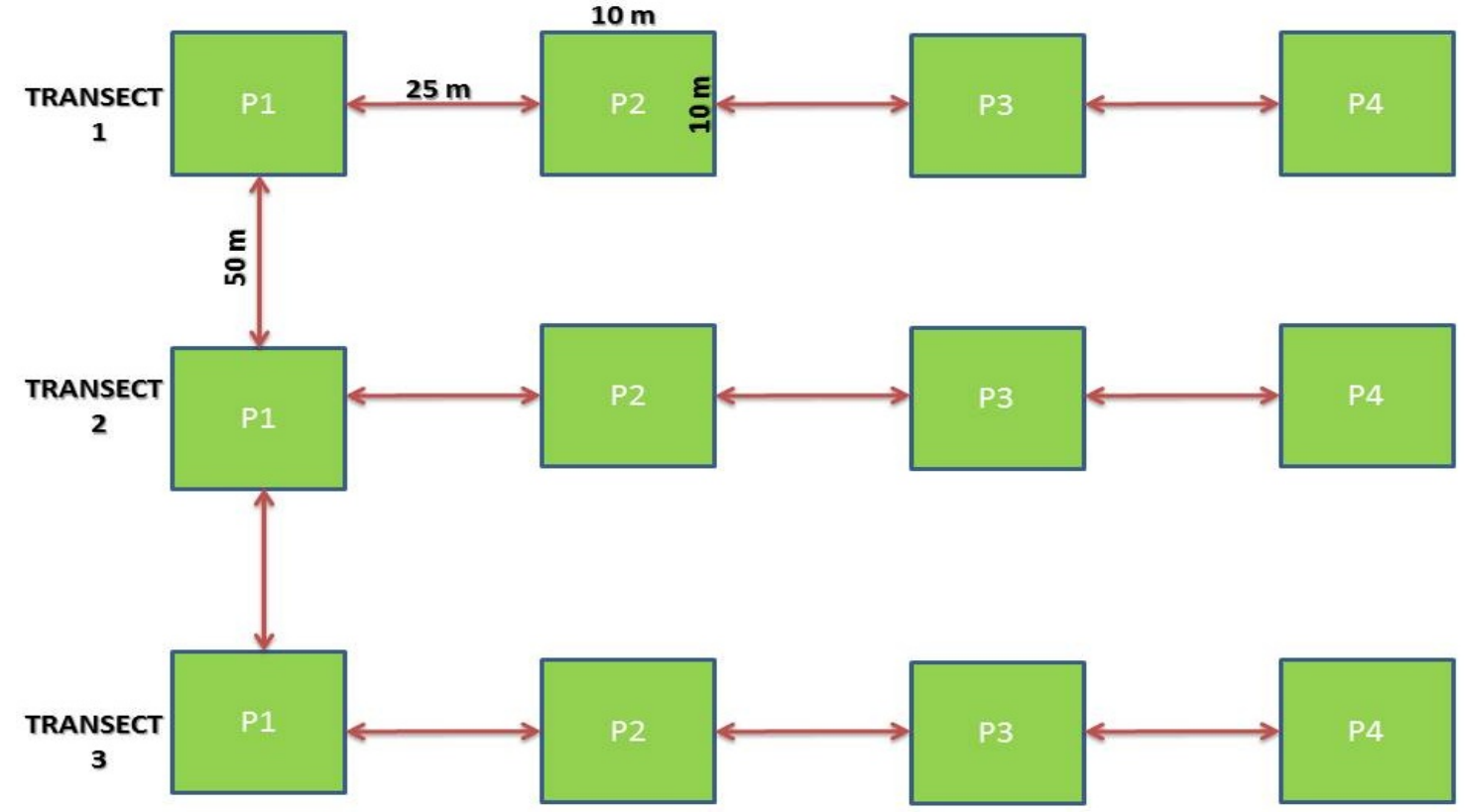

Figure 3. Sampling design used (Adapted from Kathiresan, 1990; Louca et al., 2008). P: plot. 


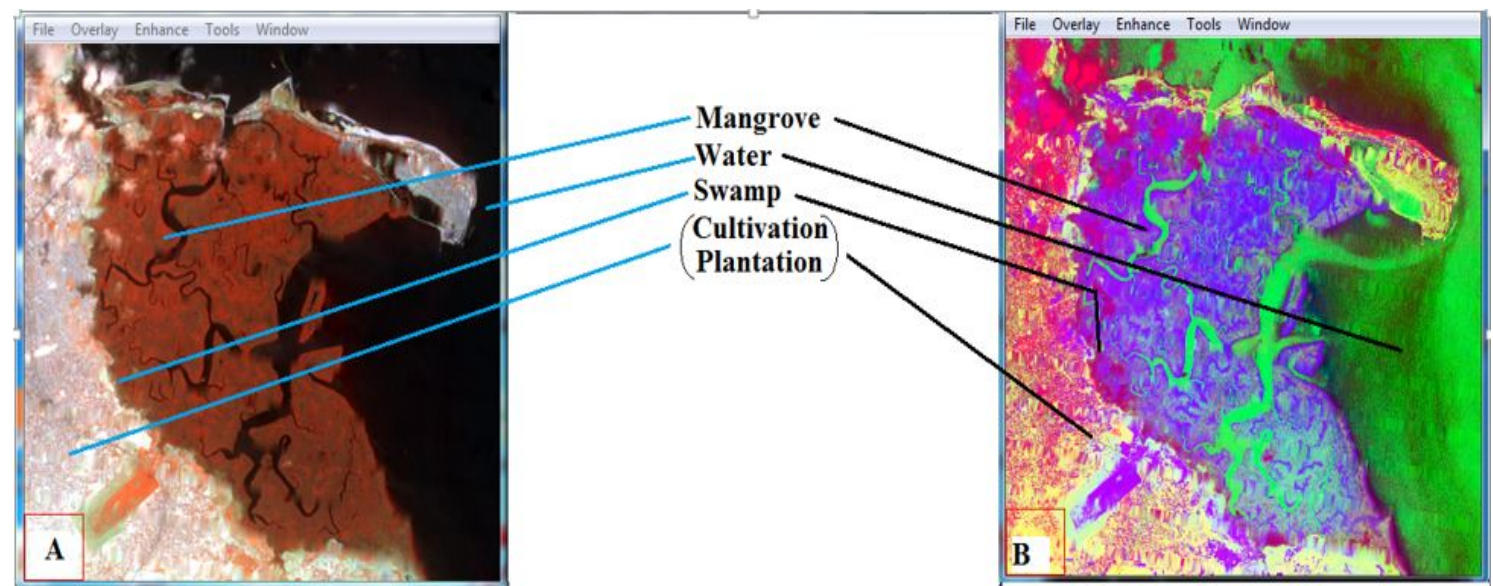

Figure 4. False color composites of Tanbi Wetland National Park, ETM+1/4/5/7 (A) and ACP1/ACP3/NDVI (B).

\subsection{Sampling Design}

A straight-line-transect method was set up for sampling environmental parameters according to Kathiresan [24]. Seven sampling stations were selected to be representative of all the land use types in TWNP. At each station, three transects were set perpendicular to the water source according to Louca et al. [25] and then four plots set in each transect to give 12 plots per land use type (Figure 3).

\subsection{Environment/Water Quality Analysis}

Water samples were collected diagonally at a depth of $10-$ $25 \mathrm{~cm}$ from 3 points at each plot to give 36 water samples per station $(\mathrm{n}=36)$. Since no significant vertical stratification has been reported in the River Gambia estuary [26, 27, 28], all water samples were collected at high tides between the hours of $6 \mathrm{am}$ and $12 \mathrm{pm}$. The physicochemical parameters i.e. salinity, $\mathrm{pH}$, dissolved oxygen (DO) and water temperature were analyzed in-situ using a YSI Pro-plus water meter, while turbidity was analyzed ex-situ using a $\mathrm{HACH}$ turbidity meter (HACH 2100P). Nitrate was analyzed by the cadmium reduction method, while phosphate was analyzed by the ascorbic acid method $[29,30]$.

To assess chlorophyll a content, 12 water samples (each of $500 \mathrm{ml}$ ) were collected at each station. Using Whatman fibre glass membrane filters (diameter $25 \mathrm{~mm}$ and porosity 0.7 $\mu \mathrm{m})$, these samples were filtered in subdued light and analyzed by fluorescence method (spectrophotometry) based on the EPA protocol 445.0 [31]. Chlorophyll a content was calculated as follows:

$$
C S, c=\frac{\text { CE, c } x \text { Extract Volume (L) } x D F}{\text { Sample Volume (L) }}
$$

Where, CS, $\mathrm{c}=$ corrected chlorophyll a concentration $(\mu \mathrm{g} / \mathrm{L})$ in the whole water sample,

$\mathrm{CE}, \mathrm{c}=$ corrected chlorophyll a concentration $(\mu \mathrm{g} / \mathrm{L})$ in the extract solution analyzed,

$\mathrm{DF}=$ dilution factor,

Extract volume $=$ volume $(\mathrm{L})$ of extract prepared before dilution
For representation of the complete seasonal cycle, sampling for the environmental studies was done during the peak discharge period of the River Gambia (September December, 2013) and repeated during the peak dry season (April - July, 2014).

\subsection{Mangrove Vegetation Dynamics}

\subsubsection{Image Selection and Acquisition}

The satellite images used in this study were Landsat images. These were downloaded from the United States Geological Survey (USGS) website (http://glovis.usgs.gov/). The images were selected based on availability for the study site's path and row i.e. 205/051 from different Landsat sensors (Table 1).

Table 1. Characteristics of the satellite images used in this research.

\begin{tabular}{|c|c|c|c|c|}
\hline Path/Row & Acquisition date & Landsat \# & Image type & $\begin{array}{c}\text { UTM } \\
\text { Zone }\end{array}$ \\
\hline $205 / 051$ & Feb 21, 1973 & 1 & MSS & $28 \mathrm{~N}$ \\
\hline $205 / 051$ & March 18, 1984 & 5 & TM & $28 \mathrm{~N}$ \\
\hline $205 / 051$ & May 09, 1995 & 5 & TM & $28 \mathrm{~N}$ \\
\hline $205 / 051$ & May 20, 2002 & 7 & ETM+ & $28 \mathrm{~N}$ \\
\hline $205 / 051$ & May 15, 2012 & 7 & ETM+ & $28 \mathrm{~N}$ \\
\hline
\end{tabular}

\subsubsection{Image Processing}

The images were pretreated in preparation for vegetation analysis. This stage involves radiance calibration of the images and the extraction (sub-setting) based on the frame of the study area. After this, the 2012 image was stripe-corrected using the gap-fill method suggested by the USGS and according to methods of Scaramuzza et al. [32]. These stripes were caused by digital malfunctions of the Landsat 7 sensor in 2003. After this, a Principal Component Analysis (PCA) and Normalized Differential Vegetation Index (NDVI) calculations were performed to create new components for the images. These together with the original bands were used to create the false color composites of the 
study site's land cover, according to methods of Thu and Populus [33].

The analysis of these false color composites was based on the principle that each land use/land cover type has a specific spectral reflectance. This is indicated in the color of that particular vegetation, characterized by its phenology and structure. With this, two sets of false color composites were generated i.e. the false color images of ETM+1/4/5/7 (A) and ACP1/ACP3/NDVI (B). Based on the clarity of the resultant images, the false color composite PCA1/PCA3/NDVI (B) was more accurate as opposed to the classic false color image $\mathrm{ETM}+1 / 4 / 5 / 7$ (A) in discriminating major components such as mangrove and swamp areas. Therefore, the most discriminative colors (in PCA1/PCA3/NDVI (B)) were retained to support the ground-truthing stage which is necessary for confirmation of the different types of land use/land cover (Figure 4). After this, a sample of 84 ground control points representative of the different land use types were selected and their geographical coordinates recorded to ease location in the field.
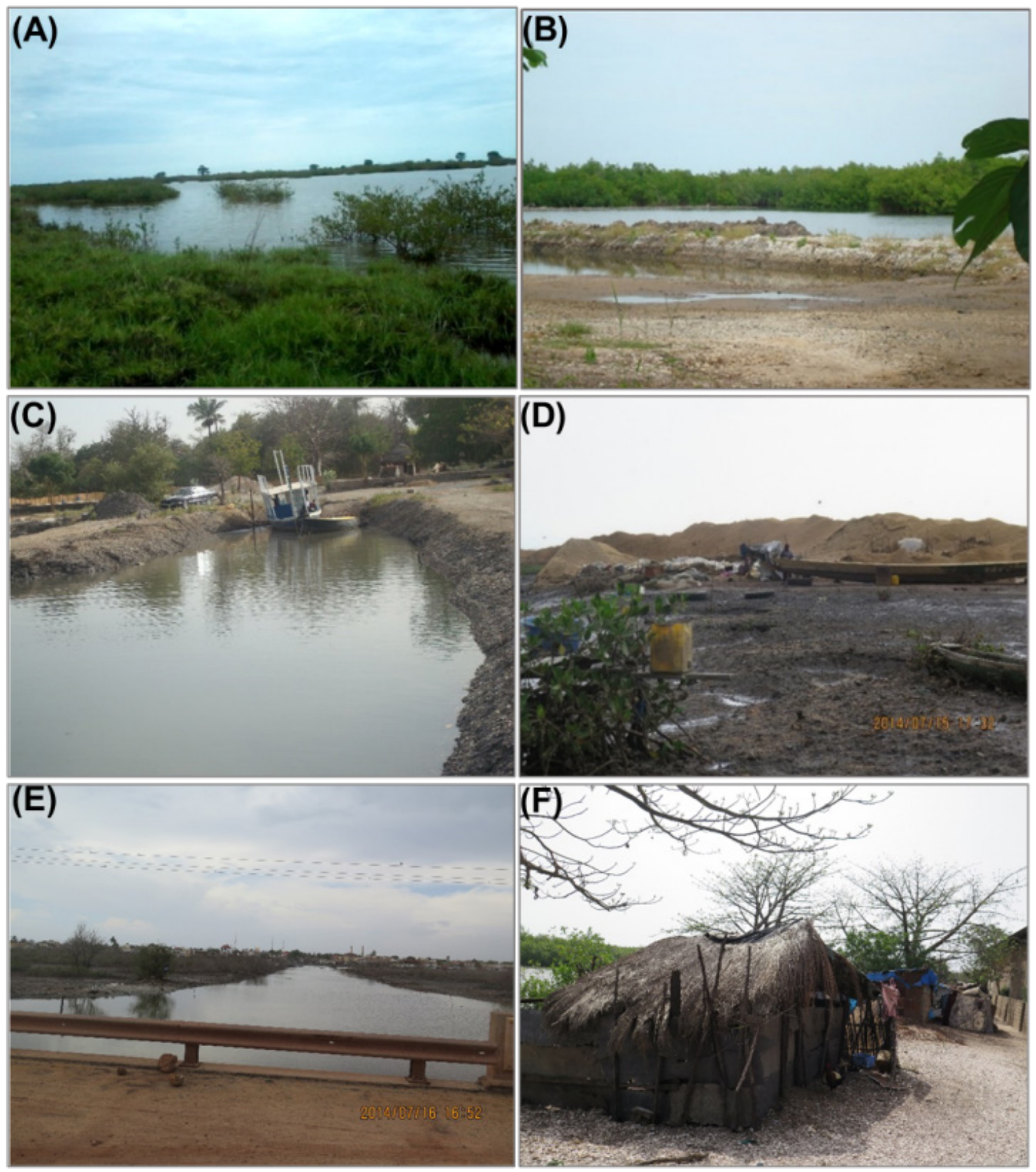

Figure 5. Pictorial view of the prominent land use/land cover features TWNP, 2014. A: Low growth at the completely fragmented zone, B: walk-bridge made from oyster shells, C: Local dock for small tourist boats, D: Peanut shells dumped in the wetland, E: Mini culvert near Banjul, F: Thatch houses built along the shores. 
For illustration of the different land uses/land cover, representative pictures were also taken of each one during the fieldwork (Figure 5). Additional data were collected to facilitate easy exploitation of the images and for familiarization with the work environment. These include historical data about the TWNP from literature [17] and those generated from the images. Layers of roads, localities, rivers etc. were digitized from the panchromatic images. Protected area and administrative zone layers were also gathered from literature and existing wetlands projects [18].

A supervised classification of images was performed using the most recent image (2012) and based on the maximum likelihood algorithm. The parcels visited (84) were divided into two (2) groups. The first batch (34 plots) was used as training in the classification. The second batch (50 plots) was used for the development of the confusion matrix (classification validation).

Multiple trials were performed to enhance the resultant image and then the same process was performed for the images of the previous years under study i.e. 1973, 1984, 1995 and 2002.

\subsubsection{Accuracy Assessment and Spatial Dynamics}

An accuracy assessment was performed in two stages: the thematic and the statistical validations based on methods of Kaufmann and Seto [34]. The thematic validation was comprised of a visual comparison between the color-composite (B) and the classification results. Historical data was also used during the accuracy assessment to aid in verification of classification results.

An overall accuracy of at least $80 \%$ and a Kappa coefficient close to 1 are expected for a good classification, based on recommended assessment scale by Blum et al. [35]. After this assessment, a median filter of $3 \times 3$ pixels was applied to eliminate isolated pixels.

The classified data which were in raster format were then converted to vector files and exported to ArcGIS for the estimation of the areas of the different land use/land cover types and the analysis of their corresponding spatial dynamics.

\subsection{Data Analysis}

Individual environmental variables for all sites were subjected to a One-way Analysis of Variance (ANOVA) $(P$ value set at $<0.05$ ) to detect significant differences per season. Pairwise student's t-test was performed to establish seasonal differences in mean values of the water variables at individual sampling stations during the rainy and dry seasons according to methods of Hayé Claire et al. [36] using R software version 3.1.2 statistical package for windows.

For establishing the relationship between long-term changes in mangrove vegetation and long-term rainfall anomalies for Banjul, annual rainfall index $\left(\mathrm{S}_{\mathrm{sy}}\right)$ was calculated starting from 1964 to 2014 according to methods of L'Hôte et al. [37], based on the formula below:

$$
\mathrm{S}_{\mathrm{sy}}=\left(\mathrm{R}_{\mathrm{sy}}-\mathrm{R}_{\mathrm{s}}\right) / \sigma_{\mathrm{s}}
$$

Where: $\mathrm{R}_{\mathrm{sv}}=$ the annual rainfall of Banjul for the year $\mathrm{y}$,

$\mathrm{R}_{\mathrm{s}}=$ the mean annual rainfall for the reference period $(1964-2014)$,

$\sigma_{\mathrm{s}}=$ the standard deviation for Banjul rainfall for the reference period (1964-2014).

A similar approach was applied to long-term atmospheric temperature data for Banjul to identify temperature anomalies during the same period (herein temperature index for Banjul).

\section{Results}

\subsection{Environment/Water Quality}

Based on the one-way ANOVA results, significant differences were recorded in mean salinity levels during the two seasons studied $(P$ value $<0.0001)$. Average salinity level was $24.5 \mathrm{ppt}$ during the rainy season. This value increased to $35.8 \mathrm{ppt}$ during the dry season. Similarly, average water temperature increased significantly ( $P$ value, $<0.001$ ) from $27.6^{\circ} \mathrm{C}$ during the rainy season to $30.2^{\circ} \mathrm{C}$ during the dry season.

Average $\mathrm{pH}$ levels did not differ significantly between the two seasons, i.e. 7.60 and 7.55 for the rainy and dry seasons respectively. Throughout the study, DO values were never critical $\left(<3 \mathrm{mgl}^{-1}\right)$ [38]. Average DO was $5.5 \mathrm{mgl}^{-1}$ during the rainy season, slightly decreasing to $5.4 \mathrm{mgl}^{-1}$ during the dry season.

Significant differences were noted in nitrate and phosphate levels between the two seasons ( $P$ value, $<0.003$ ). Average nitrate level declined from $2.7 \mathrm{mgl}^{-1}$ during the rainy season to $0.8 \mathrm{mgl}^{-1}$ in the dry season. Likewise, average phosphate level declined significantly $(P$ value, $<0.005)$ from $2.0 \mathrm{mgl}^{-1}$ during the rainy season to $0.6 \mathrm{mgl}^{-1}$ during the dry season.

Average chlorophyll a level in TWNP was generally low during the rainy season $\left(3.9 \mu \mathrm{gl}^{-1}\right)$. This declined slightly to $3.6 \mu \mathrm{gl}^{-1}$, but not significantly during the dry season $(P$ value, $0.4)$. Average turbidity levels followed a similar trend, declining significantly $(P$ value, $<0.004)$ from 11.6 NTU during the rainy to $8.2 \mathrm{NTU}$ during the dry season (Table 2).

Table 2. Summary of environmental variables and their significance levels during the rainy and dry seasons in Tanbi wetland National Park in The Gambia in 2014.

\begin{tabular}{|c|c|c|c|}
\hline Environmental Variable & $\begin{array}{c}\text { Rainy } \\
\text { season }\end{array}$ & $\begin{array}{c}\text { Dry } \\
\text { season }\end{array}$ & $\begin{array}{c}\text { Statistical } \\
\text { significance }\end{array}$ \\
\hline Salinity $(\mathrm{ppt})$ & 24.5 & 35.8 & $* * * *$ \\
\hline Dissolved oxygen $\left(\mathrm{mgl}^{-1}\right)$ & 5.5 & 5.4 & $\mathrm{~ns}$ \\
\hline Temperature $\left({ }^{\circ} \mathrm{C}\right)$ & 27.7 & 30.2 & $*$ \\
\hline $\mathrm{pH}$ & 7.6 & 7.5 & $\mathrm{~ns}$ \\
\hline Chlorophyll a $\left(\mu \mathrm{gl}^{-1}\right)$ & 3.9 & 3.6 & $\mathrm{~ns}$ \\
\hline Turbidity $(\mathrm{NTU})$ & 11.6 & 8.2 & $* *$ \\
\hline Nitrate $\left(\mathrm{mgl}^{-1}\right)$ & 2.7 & 0.8 & $* * *$ \\
\hline Phosphate $\left(\mathrm{mgl}^{-1}\right)$ & 1.7 & 0.1 & $* *$ \\
\hline
\end{tabular}

Number of stars indicates significance level. *: significant at $<0.05, * *$ : significant at $<0.01, * * *$ : significant at $<0.001, * * * *$ : significant at $<0.0001$, ns: not significant. 


\subsection{Mangrove Vegetation Dynamics and Its Relationship with Climate Variables}

Accuracy assessment was above $80 \%$ for all the images used. Kappa coefficients for the images of 1973, 1983 and 2002 scored regular, while those of 1995 and 2012 scored excellent based on the image accuracy scale of $0-1$ suggested by Blum et al. [35]. Global accuracy assessments for the images analyzed were reported in percentage as follows: 84.4 for 1973, 89.2 for 1984, 93.0 for 1995, 95.2 for 2002 and 96.5 for 2012 (Table 3).

Table 3. Accuracy assessment of images analyzed for Tanbi Wetland National Park (1973 - 2012).

\begin{tabular}{|c|c|c|}
\hline Year & Accuracy (\%) & Kappa coefficient \\
\hline 1973 & 84.43 & 0.85 \\
\hline 1984 & 89.19 & 0.88 \\
\hline 1995 & 93.04 & 0.92 \\
\hline 2002 & 95.23 & 0.86 \\
\hline 2012 & 96.54 & 0.96 \\
\hline
\end{tabular}

Notwithstanding, some confusion was noted between some of the non-mangrove LULC classes i.e. the swamp, grassland / low growth, forest and planting/cultivation (ranging from 12 to $26 \%$ ). Based on the accuracy scale, the assessment of the remotely sensed data yielded seven LULC types in TWNP. These include: Mangrove, Swamp, Forest, Water, Cultivation, Woods, and Grassland (Figure 6). Mangrove vegetation was the largest LULC class, forming $59.2 \%$ of total area coverage in 1973 and increased by $1.9 \%$ and $1.2 \%$ between the years 1973-1984 and 1984-1995 respectively. This trend however began to reverse between $1995-2002$ and $2002-2012$, declining by $7.3 \%$ and $6.6 \%$ respectively. Overall loss of mangrove vegetation in TWNP was $6 \%$ between 1973 and 2012. This is visible along the fringes of the wetland where massive number of Avicennia germinans stumps could be seen. This situation is even more pronounced in Bakau (fragmented zone) located in the Northwestern part of the park, where the mangrove vegetation is mostly comprised of Avicennia germinans. In relation, swamp coverage increased proportionally by $44.4 \%$ as mangroves declined and seemingly replacing the degraded areas (Figure 7).

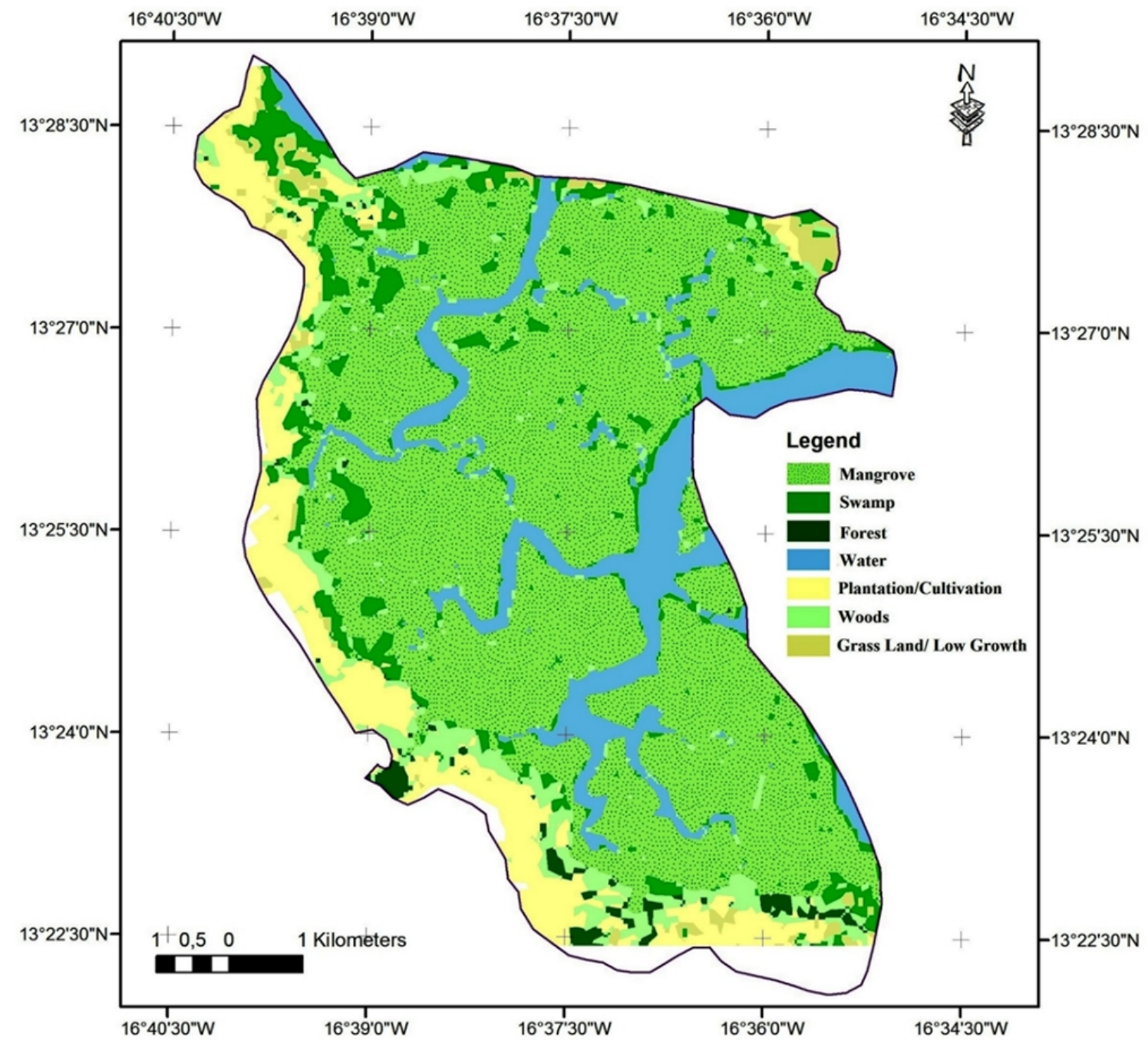

Figure 6. Land cover map of Tanbi Wetland National Park in The Gambia, for 1973. 


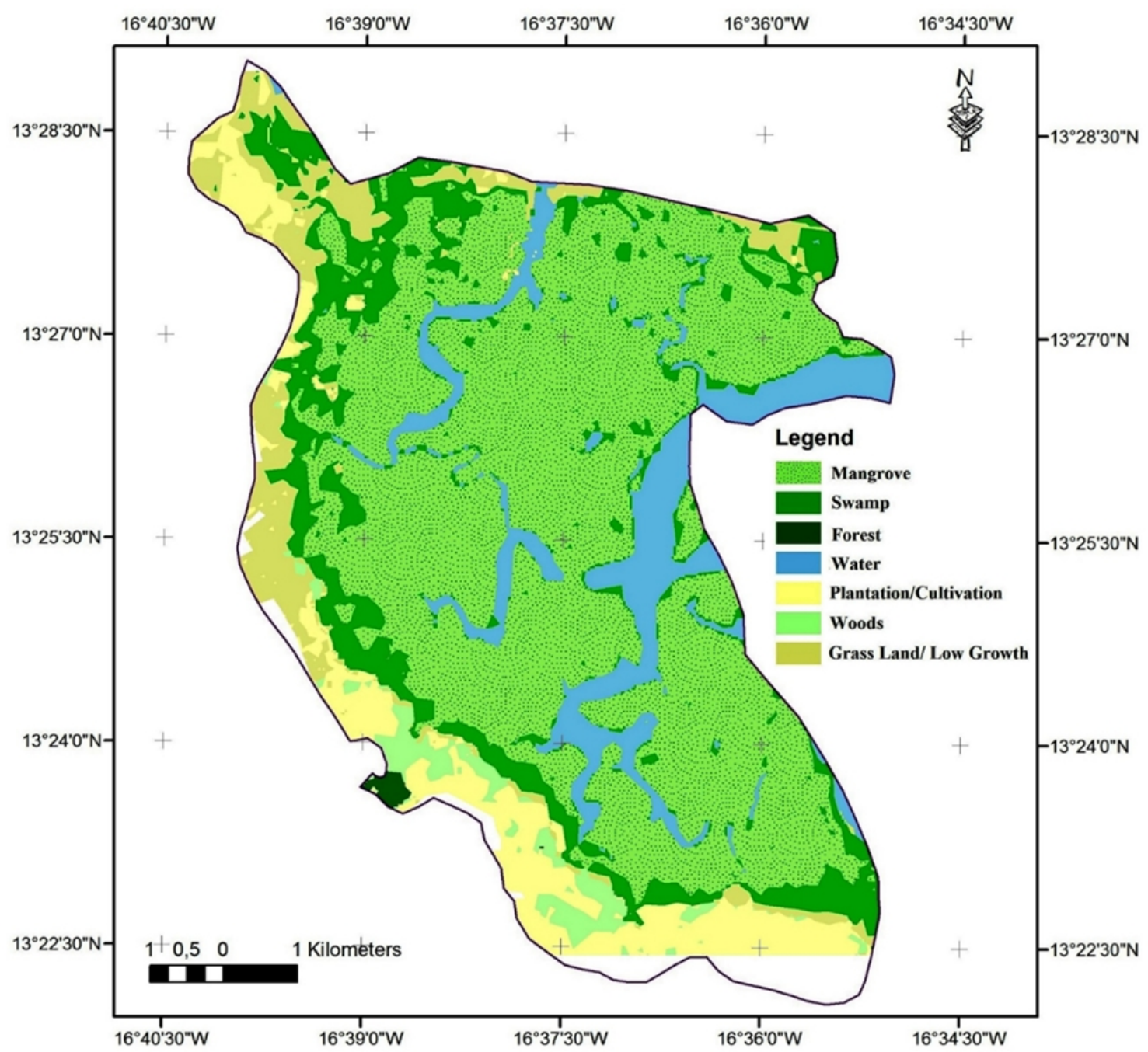

Figure 7. Land use / land cover map of Tanbi Wetland National Park in The Gambia, for 2012

Within the four-decade period, the forest areas surrounding the park declined by $311.1 \%$ to be replaced by either low growth/grassland or cultivation/plantation, especially along the Southwestern part of the park (Abuko end, oyster processing zone). A similar trend was observed for the woody areas with a decline of $112.0 \%$.

In relation to historical data of climate variables (herein rainfall and atmospheric temperatures) of Banjul, mangrove vegetation cover in TWNP declined proportionally as rainfall declined and atmospheric temperatures increased. Historical climate data showed that rainfall index for Banjul was quite positive before 1968. During this period, the rainfall index for Banjul was always above 1.4 (wet periods). Hence the focus here is on the rainfall data during and after the Sahelian drought (1972 - 2014). The mean rainfall index for the decade leading to 1973 was -0.4 (dry); further declining to -0.2 during the decade of 1984, as well as for the decade of 1994. There was a further decline in rainfall index to -0.1 during the decade leading to 2004 and then making a slight recovery to 0.01 during the decade leading to 2012 (Figure 8). 

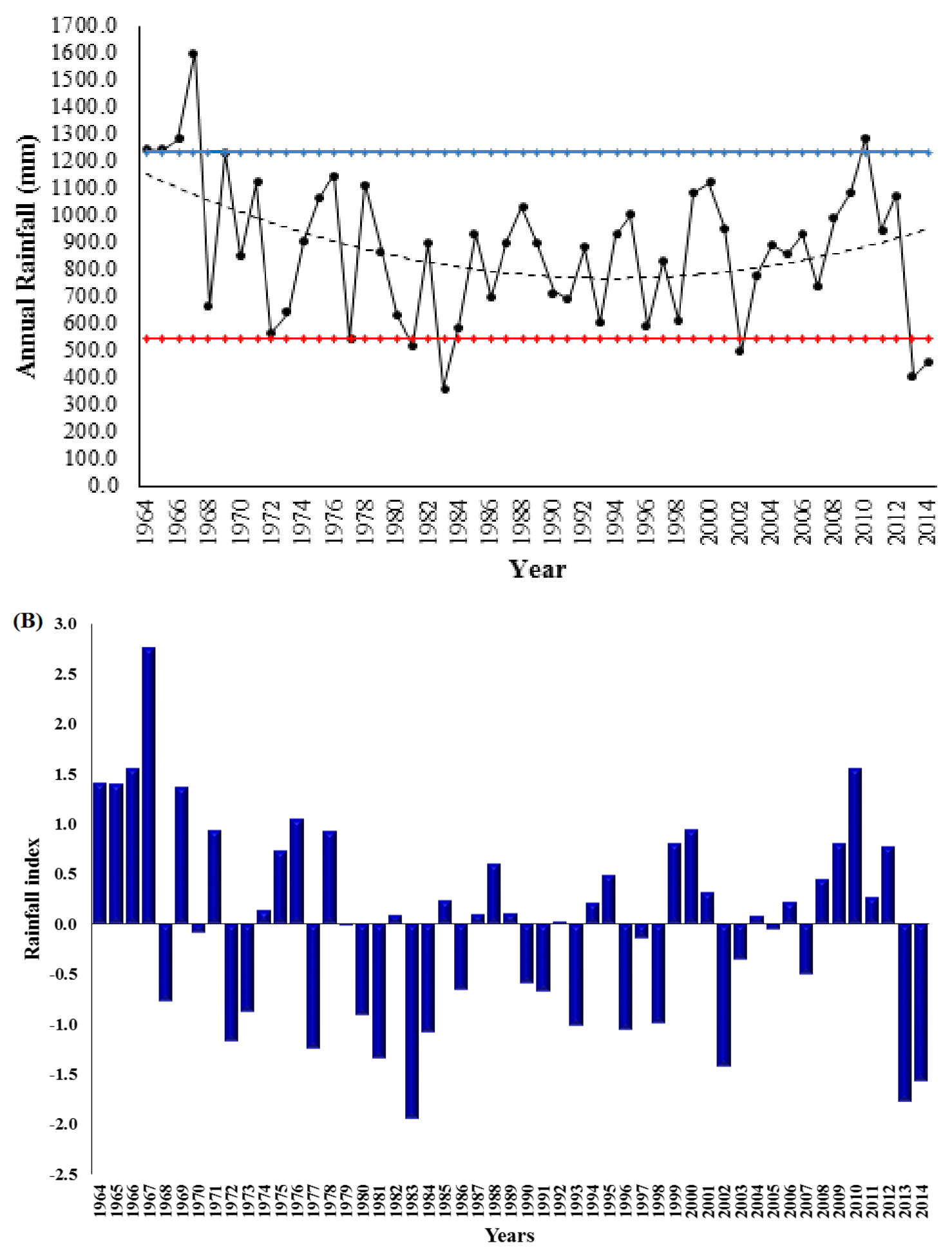

Figure 8. Long-term rainfall pattern (A) and index (B) for Banjul, 1964 - 2014 (Data source: The Gambia Meteorological Bureau, 2015). 

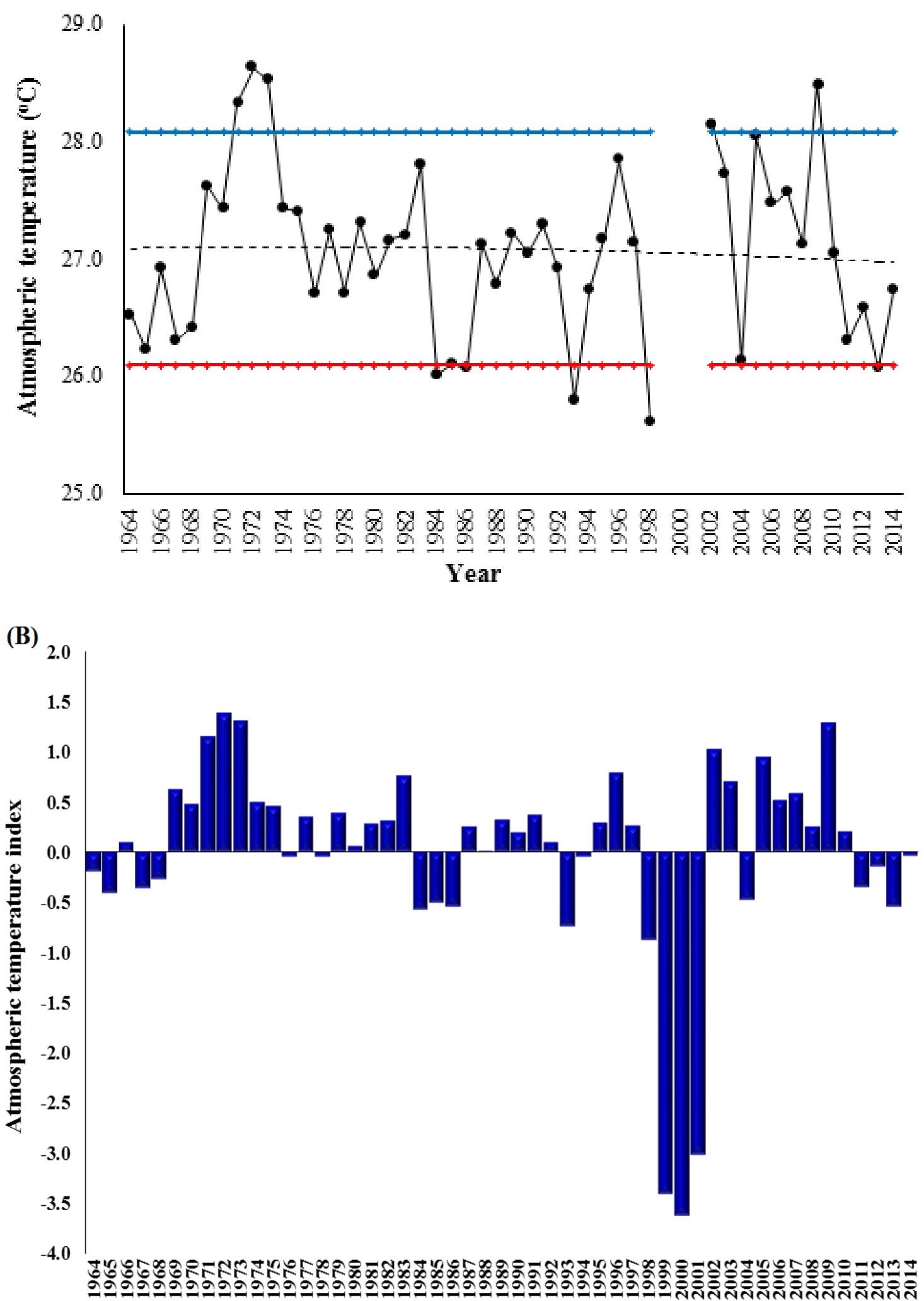

Years

Figure 9. Long-term atmospheric temperature pattern (A) and index (B) for Banjul, 1964-2014 (Data source: The Gambia Meteorological Bureau, 2015). 
Mean annual temperature index for Banjul followed a similar trend to rainfall, with indices staying below zero before the Sahelian drought in early 1970s. However, temperature indices spiked to a mean of 0.6 (hot period) in 1972 and stayed above zero for that entire decade. This declined to -0.5 (cooler period) in 1984 , but lasted only until 1987 and then spiked to a mean of 0.2 . This lasted the rest of the decade (1987-1996), after which the temperature index declined to -0.51 and remained cooler until 2002. This was followed by a steady increase in the temperature index, staying at a mean of 0.6 until 2010 and then cooling down a bit to a mean of -0.3 until 2014 (Figure 9).

In relation to the above, the area coverage for mangrove vegetation was stable during the first two decades studied, with a slight increase of $1.9 \%$ between the years $1973-1984$ and then by $1.3 \%$ from $1984-1995$. This trend however changed course with significant declines during the next two decades. Between the years 1995 - 2002 and $2002-2012$, mangrove vegetation in TWNP declined by 2.4 and $7.3 \%$ respectively, resulting in a total decline of $6 \%$ in mangrove vegetation by 2012 . Forests around the park followed a similar trend, only increasing by $14.6 \%$ during the first decade, then declining by $292.2 \%, 17.1 \%$ and $16.4 \%$ respectively during the following three decades. The grassland and swamps were the only LULC type that registered a significant increase in area coverage $(56.4 \%$ and $44.4 \%$ respectively) as environmental conditions became harsher (Tables 4 and 5).

Table 4. Percentage area of land cover classes in Tanbi Wetland National Park in The Gambia, 1973 - 2012.

\begin{tabular}{|c|c|c|c|c|c|}
\hline \multirow{2}{*}{ Land cover } & \multicolumn{5}{|c|}{ Area coverage (\%) } \\
\cline { 2 - 7 } & $\mathbf{1 9 7 3}$ & $\mathbf{1 9 8 4}$ & $\mathbf{1 9 9 5}$ & $\mathbf{2 0 0 2}$ & $\mathbf{2 0 1 2}$ \\
\hline Mangrove & 59.2 & 60.4 & 61.1 & 59.7 & 55.6 \\
\hline Swamp & 7.7 & 7.1 & 8.5 & 0.3 & 14.1 \\
\hline Forest & 1.3 & 1.5 & 0.4 & 10.9 & 10.7 \\
\hline Water & 12.1 & 11.9 & 12.2 & 6.1 & 9.3 \\
\hline Cultivation/plantation & 11.0 & 10.2 & 10.3 & 3.2 & 2.5 \\
\hline Woods & 6.6 & 5.7 & 4.0 & 11.8 & 7.5 \\
\hline Grass Land/low growth & 2.0 & 3.2 & 3.4 & & 0.3 \\
\hline
\end{tabular}

Table 5. Summary of land and cover changes in Tanbi Wetland National Park in The Gambia, 1973 to 2012.

\begin{tabular}{|c|c|c|c|c|c|}
\hline \multirow{2}{*}{ Land cover } & \multicolumn{4}{|c|}{ Decadal land use land cover changes TWNP (\%) } & \multirow{2}{*}{ Total (\%) } \\
\hline & 1973- 1984 & 1984- 1995 & $1995-2002$ & $2002-2012$ & \\
\hline Mangrove & +1.9 & +1.3 & -2.4 & -7.3 & -6.6 \\
\hline Swamp & -8.8 & +17.0 & -7.2 & +43.4 & +44.4 \\
\hline Forest & +14.6 & -292.2 & -17.1 & -16.4 & -311.1 \\
\hline Water & -1.7 & +2.7 & -12.7 & -1.4 & -13.3 \\
\hline Cultivation/plantation & -7.2 & +0.4 & -68.1 & +34.3 & -40.6 \\
\hline Woods & -16.0 & -42.1 & -24.5 & -29.3 & -112.0 \\
\hline Grassland/low growth & +35.7 & +6.5 & +71.2 & -57.0 & +56.4 \\
\hline
\end{tabular}




\section{Discussion}

\subsection{Environment/Water Quality}

For an ambient water quality regime in any given estuary, there is a need for a balanced water budget i.e. one where rainfall equilibrates evaporation on a yearly basis, so that key variables such as salinity would remain stable between successive years [39]. A lot of research has been done on seasonal variations in the estuaries of the Sahel [39, 40, 41] and of West Africa as a whole [42, 43]. The general consensus being that seasonal variations are much more pronounced within the River Gambia estuary [44,28]. The brackish water zone of the River Gambia extends from about $80 \mathrm{~km}$ in September to more than $220 \mathrm{~km}$ inland in June, while in the rainy/flood season, at least two-thirds of the estuary becomes totally fresh, oligohaline or mesohaline [25]. Thus, the high seasonal variation recorded in salinities of the rainy and dry seasons during this study is an indication of a negative runoff, which enables seawater to intrude the estuary and become concentrated by evaporation [39].

About a decade ago, average water temperatures in TWNP were 23.8 and $30^{\circ} \mathrm{C}$ for the rainy and dry seasons [23]. But these values have greatly increased as indicated in the current research, suggesting higher overall temperatures and lesser cooling effect from river flow as the region's water budget has become very low [45]. These findings are concurrent with predictions of Pagés and Citeau [39] that about $80 \%$ of the increase in estuarine salinity within the Sahel is explained by long-term variability in rainfall and evaporation. In the same vein, Pagés and Citeau [39] determined that for Sahelian estuaries such as the Kaolack inverse estuary in Southwest of the River Gambia to return to the "normalcy" it had before the Sahelian drought, an annual rainfall of $\geq 2000 \mathrm{~mm}$ is needed. However, this amount of rainfall can only be dreamed of in the Sahel, considering the recent climate scenarios. Annual rainfall went down from $1067 \mathrm{~mm}$ before 1960 to 680 between 1968 and 1977 [46]. Drastic changes in salinity, such as those due to droughts or storms that result from erratic rainfall and high atmospheric temperatures can greatly alter the number and types of plants in the estuary [38].

Indeed pollution and excessive nutrient loading have been reported to cause eutrophication and anoxic conditions unsuitable for supporting marine life in estuaries surrounded by human activities such as agriculture and industry [36]. Although, nutrient concentrations in estuaries vary according to surrounding land use, season, and geology [38], nutrient levels recorded during this research were way below the critical point, ruling out pollution as an ecosystem destabilizer in TWNP. While ruling out a case of excess nutrients being released from land uses such as agriculture and settlement, this also points to a possible situation of nutrient deficiency, which has great implications for vegetation such as mangrove. Nitrogen and phosphorus in particular are of great importance as they are essential in the growth of aquatic plants [38].

\subsection{Mangrove Vegetation Dynamics}

Generally, all types of land use in TWNP were well mapped, especially the mangroves which are our main interest. Despite the high precision maps, some land uses had important confusions that are explicable by soil moisture and spatial structure. Indeed, soil moisture under the Grassland/low growth and woods is the basis for the confusion between the two classes and the swamps. Spatially, plantation and cultivation are created in natural surfaces (grassland/low growth, wood). These artificial surfaces often look like the grassland/low growth, hence the confusion between them. While such confusion could be reduced by using a generalized classification of different types of vegetation as one class, it would divert focus from gregarious species such as mangroves which are the most important part of the wetland.

The mangroves of the TWNP were predicted to be undergoing a short-term lack of rejuvenation [47]. From field observations of the seemingly intact nature of the mangrove vegetation, this phenomenon appears to have persisted as most of the vegetation is of uniform height ( $\leq 3$ meters), lacking younger/smaller recruits. Such occurrences signify a response to swift changes in hydrology, in this case excess salinity [11]. Drastic changes in hydrology were reported to induce stunting of Avicennia marina stands and denaturing of terminal buds in Rhizophora mangle seedlings in the USA [10].

Likewise, the mangrove estuaries of the Sahel have suffered some of the most drastic ecosystems changes since the drought in the early 1970s [39]. The increase in atmospheric temperatures, erratic rains and prolonged droughts have led to reduced habitat integrity and lower ecosystem services/functions in many Sahelian estuaries [9] and in many cases, the formation of inverse estuaries [39]. For instance, exponential increase in salinity of the Casamance estuary in Senegal was reported to have completely eradicated Rhizophora mangle stands, while the few Avicennia germinans stands that survived got severely stunted [40].

In relation, the low diversity of the mangrove species in TWNP points to long-term instability of salinity condition. Maniatis [23] reported that the mangrove vegetation in TWNP is comprised of only four species, even though about nine true mangrove species exist in the Sahelian region [48]. Most mangroves in West Africa have undergone serious degradation due to deforestation, as humans seek vegetation for fuel use and clearing for agricultural land [49]. Evidences of these are usually noticed in the sparseness of the mangrove vegetation in question and the presence of tree stumps $[18,20]$. Except at Bakau (completely fragmented zone), these signs were absent in TWNP, indicating negligible use of the wetland for the aforesaid purposes.

Maniatis [23] also reported dwarfism in the two major 
mangrove species and a negative correlation between canopy height and salinity in TWNP. All of these indicate mangrove species' response to long-term seasonal hyper-salinity, in the form of reduced growth and decreased success in seedling $[50,51,52]$. In a study in Pichavaram (India), natural causes of mangrove degradation were attributed to high salinity, low levels of available nutrients and low microbial counts [10]. The large amounts of brackish water accumulated during the summer turns hyper-saline, ultimately killing/retarding mangroves [10]. In relation, the River Gambia estuary has one of the most drastic seasonal variations in the world; from extensive floods during the peak rainy season to overwhelming salt intrusions during the peak dry season [25], leading to insufficient time for adaptation/succession by any given species [27].

Even though climate effects on human systems are often difficult to discern from other adaptation processes [53], the low percentage $(6 \%)$ of depleted mangrove cover indicates nill/negligible human impacts on the mangroves of the TWNP. In addition, over the past couple of decades, conservation efforts have been intensified in and around the coastal zones of The Gambia. Apart from the ratification of almost all climate change and biodiversity accords [54], The Gambia has followed up at national level by acts such as the formulation and implementation of the Coastal Zone Management Plan [55]. The Tanbi Wetland was designated a national park in 2007 [17], local awareness creation programs instituted for vulnerable coastal communities and for the first time in West Africa, exclusive user and co-management rights were awarded to women groups involved in oyster collection [56]. These activities have paid off in the form of reduced human interference in the TWNP.

From all indications, mangroves of the TWNP are not as productive as expected because of their old age. In a study comparing the nursery role of young $(3-12$ years) versus old (>60 years) mangroves, Manson et al. [57] reported a high compaction in sediments and excess deposition of leave litter/organic matter in the latter. This can affect nutrient recycling and lower the rate of nutrient utilization and export into the open coast [58]. These are in line with recent findings indicating that vegetation cover in TWNP is seemingly intact with no noticeable growth since pre-independence days (1965) [23]. This is a uniquely bizarre ecological situation that has not been reported elsewhere and is explicable by the long-term lack of rejuvenation stemming from low growth and seedlings survival in estuaries with unstable hydrological regimes [52].

The impacts of long-term changes in climate variables on West African estuaries have been reported by many [59]. Rainfall anomalies following the Sahelian drought are the likely cause for the current degraded state of mangroves in TWNP. Since the period from $1971-2000$ were the driest three decades ever of the $20^{\text {th }}$ century [37], the slight recovery in rainfall/wet years realized after the year 2000 are actually still "dry years" when compared to the long-term rainfall averages [37]. Thus, the current findings indicate that mangrove vegetation in TWNP is suffering the long-term effects of climate-induced hydrological changes.

\section{Conclusions}

The findings from this research indicate that the mangroves of TWNP have been very well conserved with minimum human interference. This is remarkable for a natural resources-dependent country such as The Gambia. We conclude that climate change is taking its toll on the habitat integrity through excessive seasonal hyper-salinity, which is a major cause for the loss of mangrove vegetation in the Sahelian and Sahelo-Sudanian estuaries.

Climate-induced mangrove dwarfism is evident in TWNP and natural species rejuvenation is nearly impossible due to erratic seasonal changes in hydrology. Mangrove seedlings/propagules have a near-zero chance of naturally surviving the high variations on their own. Thus, we propose direct human intervention through mangrove replanting exercises. This of course will require specialized replanting methods using saplings instead of propagules to ensure greater survival, as the saplings already have a relatively well developed vascular system when compared to propagules which may end up being washed away to less suitable zones during the flood season or become rotten when the estuary becomes hyper-haline.

To increase ecological knowledge about mangroves in TWNP, there is a need for further research to assess long-term changes in species zonation, as well as seedlings/sapling survival in TWNP. This will serve as a reliable guide for choosing mangrove species most suitable for revegetation projects within TWNP and the River Gambia estuary as well as prevent low survival rates as encountered in past revegetation programs in The Gambia.

More research is needed on the response mechanisms of estuarine flora and fauna to climate change. In addition, identifying and assessing success rates of state-run interventions/alternative livelihoods will provide better adaptation strategies to climate change; while at the same time recognizing the role of the mangrove estuaries as a life-supporting system for vulnerable coastal communities.

\section{Acknowledgements}

Data collection for this research was sponsored by the German Federal Ministry of Education and Research (BMBF) through the West Africa Science Service Center on Climate Change and Adapted Land Use (WASCAL). The analysis and manuscript development phase was sponsored by the Alexander von Humboldt Foundation (AVH) through its Climate Protection Initiative, 2016 fellowship. To each one of these institutions, we express our most profound gratitude for the opportunity and all the support they offered us during this research. 


\section{REFERENCES}

[1] Sremongkontip, S., Hussin, Y.A. \& Groenindijk, L. (2000). Detecting changes in the mangrove forests of southern Thailand using remotely sensed data and GIS. International Archives of Photogrammetry and Remote Sensing, XXXIII (1): 567-574.

[2] Syed, M., Hussin, Y. \& Weir, M. (2001). Detecting fragmented mangroves in the Sundarbans, Bangladesh using optical and radar satellite images. In: Asian Conference on Remote Sensing, National University of Singapore, Singapore, $6 \mathrm{p}$.

[3] Vannucci, M. (2001). What is so special about mangroves? Revista brasleira de biologia, 61(4): 599-603.

[4] McKee, K.L. (1996). Mangrove Ecosystems: Definitions, Distribution, Zonation, Forest Structure, Trophic Structure, and Ecological Significance. In: Feller, I. C., \& Sitnik, M., eds. Mangrove ecology: a manual for a field course. Smithsonian Environmental Research Center, Smithsonian Institution, Maryland, United States of America, $6 \mathrm{p}$.

[5] Baran, E. (2000). Biodiversity of Estuarine Fish Faunas in West Africa. Naga, The ICLARM Quarterly, 23: 4 - 9.

[6] IUCN. (2010). National Diagostric Report for The Gambia on Climate Change Vulnerability, International Union for Conservation of Nature (IUCN), Banjul, The Gambia, $132 \mathrm{p}$

[7] Van Lavieren, H., Spalding, M., Alongi, D., Kainuma, M., Clüsener-Godt, M., Adeel, Z. (2012). Securing the Future of Mangroves. A Policy Brief. UNU-INWEH, UNESCO-MAB with ISME, ITTO, FAO, UNEP-WCMC and TNC. 53 p.

[8] Spalding, M., Blasco, F. \& Field, C. eds. (1997). World Mangrove Atlas. The International Society for Mangrove Ecosystems. Okinawa, Japan, 178 p.

[9] Panfili, J., Mbow, A., Durand, J.-D., Diop, K., Diouf, K., Thior, D., Ndiaye, P., Laë, R. (2004). Influence of salinity on the life-history traits of the West African black-chinned tilapia (Sarotherodon melanotheron): Comparison between the Gambia and Saloum estuaries. Aquatic Living Resources, 17: $65-74$

[10] Kathiresan, K. (2002). Why are mangroves degrading? Current Science, 83(10): 1246-1249.

[11] Austin, J., Zhang, L., Jones, R.N., Durack, P., Dawes, W., Hairsine, P. (2010). Climate change impact on water and salt balances: An assessment of the impact of climate change on catchment salt and water balances in the Murray-Darling Basin, Australia. Climatic Change, 100: 607-631

[12] Williams, L. \& Rota, A. (2011). Impact of climate change on fisheries and aquaculture in the developing world and opportunities for adaptation. Fisheries Thematic paper. International Fund for Agricultural Development, Rome, Italy, $20 \mathrm{p}$.

[13] The U.S. Fish and Wildlife Services. (1999). Multi-Species Recovery Plan for South Florida. Ecological Communities, Florida, United States of America, $34 \mathrm{p}$.

[14] Lubbers, L., Boynton, W.R. \& Kemp, W.M. (1990).
Variations in structure of estuarine fish communities in relation to abundance of submersed vascular plants. Marine Ecology Progress Series, 65: 1-14.

[15] Jallow, B.P., Toure, S., Barrow, M.M.K., Mathieu, A.A. (1999). Coastal zone of The Gambia and the Abidjan region in Côte d'Ivoire: sea level rise vulnerability, response strategies, and adaptation options. Climate Research, 12: $129-136$.

[16] National Environment Agency. (2010). The Gambia State of the Environment Report Second Edition. National Environment Agency, Banjul, The Gambia, 263 p.

[17] National Environment Agency. (2010). The Gambia State of the Environment Report Second Edition. National Environment Agency, Banjul, The Gambia, 263 p.

[18] Hirani, P. (2005). Ethnoecological Study of the Mangroves of the Tanbi Wetland Complex, The Gambia. Master's thesis submitted to the University of Vrije, Brussels, Belgium 129 p.

[19] Lee, V., Tobey, J., Castro, K., Crawford, B., Dia, I.M., Drammeh, O., Tanvi, V. (2009). Marine Biodiversity Assets and Threats Assessment for WAMER. Gambia-Senegal Sustainable Fisheries Project, Banjul, The Gambia, 47 p.

[20] Satyanarayana, B., Bhanderi, P., Debry, M., Maniatis, D., Fore, F., Badgie, D., Jammeh, Kawsu., Vanwing, T., Farcy, C., Koedam, N., Dahdouh-Guebas, F. (2012). A socio-ecological assessment aiming at improved forest resource management and sustainable ecotourism development in the mangroves of Tanbi Wetland National Park, the Gambia. West Africa Ambio, 41: 513-526.

[21] Camara, A.S. (2012). Protected Areas Resilient to Climate Change, PARCC West Africa. National Data Collection Report: UNEP-WCMC, Banjul, The Gambia, 42 p.

[22] Crow, B. \& Carney, J. (2013). Commercializing Nature: Mangrove Conservation and Female Oyster Collectors in The Gambia. Antipode Foundation Ltd, Antipode, 00(00): 1-19.

[23] Maniatis, D. (2005). Retrospective Study of the Mangroves of the Tanbi Wetland Complex. Master's thesis submitted to the University of Vrije, Bussel, Belgium 129p.

[24] Kathiresan, K. (1990). Methods of studying mangroves. In Methods of Studying Mangroves. Annamalai University, Annamalai Nagar, India, $10 \mathrm{p}$.

[25] Louca, V., Lindsay, S.W., Majambere, S., Lucas, M.C. (2008). Fish community characteristics of the lower Gambia River floodplains: A study in the last major undisturbed West African river. Freshwater Biology, 54: 254-271.

[26] Darboe, F.S. (2002). Fish Species Abundance and Distribution in the River Gambia Estuary. UNU - Fisheries Training Programme. Final project report, Reykjavik, Iceland, $40 \mathrm{p}$.

[27] Albaret, J.-J., Simier, M., Darboe, F.S., Ecoutin, J.-M., Raffray, J., Tito de Morais, L. (2004). Fish diversity and distribution in the Gambia Estuary, West Africa, in relation to environmental variables. Aquatic Living Resources, 17: 3546.

[28] Guillard, J., Simier, M., Albaret, J.-J., Raffray, J., Sow, I., Tito de Morais, L. (2012). Fish biomass estimates along estuaries: A comparison of vertical acoustic sampling at fixed stations and purse seine catches. Estuarine, Coastal and Shelf Science, 107: 105-111. 
[29] HACH. (2005a). Nitrate, Cadmium Reduction Method. Hach Company/Hach Lange GmbH. Method 584(3): 1-10.

[30] HACH. (2005b). Phosphorus, Ascorbic Acid Method. Hach Company/Hach Lange GmbH. Method 8048(3): 1-8

[31] Arar, E.J. \& Collins, G.B. (1997). In vitro determination of chlorophyll a and pheophytin a in marine and freshwater algae by fluorescence. U.S. Environmental Protection Agency, Method 445.0, Revision 1.2, Cincinnati, Ohio (USA), pp 122.

[32] Scaramuzza, P., Micijevic, E. \& Chander, G. (2004). SLC Gap-Filled Products Phase One Methodology. United Staed Geolodical Survey (USGS), United States of America, 5 p.

[33] Thu, P.M. \& Populus, J. (2007). Status and changes of mangrove forest in Mekong Delta: Case study in Tra Vinh, Vietnam. Estuarine, Coastal and Shelf Science, 71(1-2): 98109.

[34] Kaufmann, R.K. \& Seto, K.C. (2001). Change detection, accuracy, and bias in a sequential analysis of Landsat imagery in the Pearl River Delta, China: Econometric techniques. Agriculture, Ecosystems and Environment, 85: 95-105.

[35] Blum A., Feldmann L., Bresler F., Jounny P., Briançon S., Régent D. (1995). Intérêt du calcul du coefficient kappa dans l'évaluation d'une méthode d'imagerie. Measuring agreement as an evaluation of a diagnostic imaging. European Journal of Radiology 76(7): 441- 443.

[36] Hayé, C.V., Dongui, B.K., Pellerin, J., Trokourey, A. (2009). Pollution evaluation in the estuary bay of Bietri, Abidjan, Côte d'Ivoire. Journal of Oceanography, Research and Data, 2: $1-11$.

[37] L’Hôte, Y., Mahé, G., Somé, B., Triboulet, J.P. (2002). Analysis of a Sahelian annual rainfall index from 1896 to 2000; the drought continues. Hydrological Sciences Journal, 47(4): 563-572.

[38] US EPA. (2006). Volunteer Estuary Monitoring: A Methods Manual. Second Edition., J. Ronald L. Ohrel \& K. M. Register, eds., Environmental Protection Agency (EPA), Washington DC (United States), 396 p.

[39] Pagés, J. \& Citeau, J. (1990). Rainfall and salinity of a sahelian estuary between 1927 and 1987. Journal of Hydrology, 113: 325-341.

[40] Savenije, H.H.G. \& Pagés, J. (1992). Hypersalinity - a Dramatic Change in the Hydrology of Sahelian Estuaries. Journal of Hydrology, 135(1-4): 157-174.

[41] Ecoutin, J.-M., Simier, M. Albaret, J.-J., Laë, R., Raffray, J., Sadio, O., Tito de Morais, L. (2014). Ecological field experiment of short-term effects of fishing ban on fish assemblages in a tropical estuarine MPA. Ocean \& Coastal Management, 100: 74-85.

[42] Anthony, E.J. (2004). Sediment dynamics and morphological stability of estuarine mangrove swamps in Sherbro Bay. West Africa Marine Geology, 208: 207-224.

[43] White, S.M., Ondračková, M. \& Reichard, M. (2012). Hydrologic Connectivity Affects Fish Assemblage Structure, Diversity, and Ecological Traits in the Unregulated Gambia River, West Africa. Biotropica, 44(4): 521-530.

[44] Ecoutin, J.M., Simier, M., Albaret, J.J., Laë, R., Tito de Morais, L. (2010). Changes over a decade in fish assemblages exposed to both environmental and fishing constraints in the Sine Saloum estuary (Senegal). Estuarine, Coastal and Shelf Science, 87(2): 284-292.

[45] Schlenk, D. \& Lavado, R. (2011). Impacts of climate change on hypersaline conditions of estuaries and xenobiotic toxicity. Aquatic Toxicology, 105(3-4): 78-82.

[46] Marius, C. (1982). Acid Sulphate Soils of the Mangrove Area of Senegal and Gambia. Office de la Recherche Scientifique et Technique Outre-Mer, Paris, France, 29 p.

[47] Dahdouh-Guebas, F. \& Koedam, N. (2002). A synthesis of existent and potential mangrove vegetation structure dynamics from Kenyan, Sri Lankan and Mauritanian case-studies. Bulletin Seances Academie Recerche Sciencs Outre-Mer, 48: 487-511.

[48] Corcoran, E., Ravilious, C., Skuja, M. (2007). Mangroves of Western and central Africa. Regional Seas Programme/UNEP-WCMC, Cambridge, United Kingdom, 92 p.

[49] Dimobe, K., Ouédraogo, A., Soma, S., Goetze, D., Porembski, S., Thiombiano, A. (2015). Identification of driving factors of land degradation and deforestation in the Wildlife Reserve of Bontioli (Burkina Faso, West Africa). Global Ecology and Conservation, 4: 559-571.

[50] Feller, I.C. (1995). Effects of Nutrient Enrichment on Growth and Herbivory of Dwarf Red Mangrove Effects of Nutrient Enrichment on Growth and Herbivory of Dwarf Red Mangrove. Ecological Monographs, 65(4): 477-505.

[51] Dahdouh-Guebas, F., De Bondt, R., Abeysinghe, P.D., Kairo, J.G., Cannicci, S., Triest, L., Koedam, N. (2004). Comparative study of the disjunct zonation pattern of the grey mangrove Avicennia marina (Forsk.) Vierh. in Gazi Bay (Kenya). Bulletin of Marine Science, 74(2): 237-252.

[52] De Ryck, D.J.R., Robert, E.M.R., Schmitz, N., Van der Stocken, T., Di Nitto, D., Dahdouh-Guebas, F., Koedam, N. (2012). Size does matter, but not only size: Two alternative dispersal strategies for viviparous mangrove propagules. Aquatic Botany, 103: 66-73.

[53] Mertz, O., Halsnaes, K., Olesen, J.E., Rasmussen, K. (2009). Adaptation to climate change in developing countries. Environmental Management, 43: 743-752.

[54] Lauer, H. \& Eguavoen, I. (2016). Mainstreaming Climate Change Adaptation into Development in the Gambia: A Window of Opportunity for Transformative Processes? In: Leal W.F (ed) Innovation in Climate Change Adaptation. Springer Climate Change Management Series 8740, pp 87-98.

[55] Njie, J.R.S. (2004). Legal and Institutional Profile, Coastal Zone Management Act - Profile. Torodo Chambers, Banjul, The Gambia, $54 \mathrm{p}$.

[56] USAID-BaNafaa Project. (2014). Gambia-Senegal Sustainable Fisheries Project (USAID-BaNafaa), Final Report. University of Rhode Island, Rhode Island, USA, $144 \mathrm{p}$.

[57] Manson, F.J., Loneragan, N.R., Skilleter, G.A., Phinn, S.R. (2005). An Evaluation of the Evidence for Linkages between Mangroves and Fisheries: A Synthesis of the Literature and Identification of Research Directions. Oceanography and Marine Biology: An Annual Review, 43: 483-513. 
[58] Slomp, C.P. (2011). Phosphorus Cycling in the Estuarine and Coastal Zones: Sources, Sinks, and Transformations. Treatise on Estuarine and Coastal Science, 5: 201-230.
[59] Blaber, S.J.M. (2013). Fishes and fisheries in tropical estuaries: The last 10 years. Estuarine, Coastal and Shelf Science, 135: 57-65. 